\title{
Amino Acid Substitutions in the Hepatitis C Virus Core Region and Lipid Metabolism Are Associated with Hepatocarcinogenesis in Nonresponders to Interferon plus Ribavirin Combination Therapy
}

\author{
Yuya Seko ${ }^{a}$ Norio Akuta $^{a}$ Fumitaka Suzuki $^{a}$ Yusuke Kawamura ${ }^{a}$ \\ Hitomi Sezaki $^{a}$ Yoshiyuki Suzuki $^{a}$ Tetsuya Hosaka $^{a}$ Masahiro Kobayashi $^{\mathrm{a}}$ \\ Mariko Kobayashi $^{\mathrm{b}}$ Satoshi Saitoh ${ }^{\mathrm{a}}$ Yasuji Arase $^{\mathrm{a}}$ Kenji lkeda $^{\mathrm{a}}$ \\ Hiromitsu Kumada ${ }^{a}$ \\ ${ }^{a}$ Department of Hepatology, and ${ }^{b}$ Liver Research Laboratory, Toranomon Hospital, Tokyo, Japan
}

\author{
Key Words \\ Hepatitis C virus - Genotype - Ribavirin • Interferon • \\ Hepatocellular carcinoma $\cdot$ Core region $\cdot$ High-density \\ lipoprotein cholesterol $\cdot$ IL28B
}

\begin{abstract}
Background: Substitution of amino acid 70 and/or 91 in the core region of hepatitis $C$ virus (HCV) genotype $1 \mathrm{~b}(\mathrm{HCV}-1 \mathrm{~b})$ is an important predictor of hepatocellular carcinoma (HCC), but its impact on HCC in nonresponders to interferon (IFN) and ribavirin (RIB) combination therapy is not clear. Methods: A total of 292 patients with HCV-1b-related chronic liver disease who did not achieve a sustained virological response to 24-48 weeks of IFN+RIB combination therapy were included in a follow-up study to investigate the risk factors for HCC. Results: Sixteen patients developed HCC during the follow-up. The cumulative HCC rates were 5.0, 13.1 and 16.9\% at the end of 3, 5 and 7 years, respectively. Multivariate analysis identified substitution of core amino acid 70 (Gln70/ His70; hazard ratio 4.64, $p=0.018$ ) and low serum levels of high-density lipoprotein cholesterol $(<50$ mg/dl; hazard ra-
\end{abstract}

tio 9.35, $p=0.041$ ) as determinants of HCC. Gender, stage of fibrosis and interleukin-28B showed no such relationship. Conclusions: Amino acid substitution in the core region of $\mathrm{HCV}-1 \mathrm{~b}$ and low serum levels of high-density lipoprotein cholesterol are significant and independent predictors of HCC in nonresponders to IFN+RIB combination therapy. These results emphasize the importance of viral and lipid metabolic factors in the development of HCC after combination therapy.

Copyright $\odot 2012$ S. Karger AG, Basel

\section{Introduction}

Infection with hepatitis $\mathrm{C}$ virus (HCV) is often chronic and can progress to cirrhosis and hepatocellular carcinoma (HCC) $[1,2]$. At present, interferon (IFN), in combination with ribavirin (RIB), is the mainstay for treatment of $\mathrm{HCV}$ infection. In Japan, more than $70 \%$ of $\mathrm{HCV}$ infections are caused by HCV genotype $1 \mathrm{~b}(\mathrm{HCV}-1 \mathrm{~b})$ and are associated with a high viral load, making their treatment difficult [3].

\section{KARGER}

Fax +4161306 1234

E-Mail karger@karger.ch

www.karger.com (c) 2012 S. Karger AG, Basel

$0300-5526 / 13 / 0561-0013 \$ 38.00 / 0$

Accessible online at:

www.karger.com/int
Yuya Seko, MD

Department of Hepatology, Toranomon Hospital

2-2-2 Toranomon

Minato-ku, Tokyo 105-0001 (Japan)

Tel. +81 33588 1111, E-Mail yseko523@ toranomon.gr.jp 
IFN monotherapy slightly reduces the rates of HCC and normalization of alanine transaminase [4-6]. Furthermore, IFN plus RIB combination therapy also minimizes the risk of HCC, especially among patients who achieve a sustained virological response (SVR) [7]. However, there are currently no suitable factors that could be used to predict HCC in patients who receive the combination therapy but do not achieve SVR.

Several factors have been found to correlate with HCVrelated HCC, such as old age, male sex, advanced histopathological stage of liver damage, alcohol intake, HCV genotype and hepatic steatosis [6,8-12]. Furthermore, mutations in a region spanning amino acids (aa) 22092248 within the NS5A protein, the so-called IFN sensitivity-determining region (ISDR) [13], and substitution of aa $70 / 91$ in the core region of HCV-1b [14] as viral-related factors, and genetic variation near the interleukin-28B (IL28B) gene as a host-related factor [15] are also used to predict HCC. The aim of the present study was to identify the viral- and host-related predictive factors for HCC in patients on IFN plus RIB combination therapy (IFN+RIB) who did not achieve SVR. For this purpose, we recruited 292 patients with HCV-related chronic liver disease who did not achieve SVR after 24-48 weeks of IFN+RIB.

\section{Materials and Methods}

\section{Patients}

A total of 1,540 HCV-1b-infected adult Japanese patients were consecutively recruited into a study of combination therapy with IFN [IFN or pegylated (PEG)-IFN] plus RIB between March 1999 and October 2010 at Toranomon Hospital, Tokyo, Japan. Among them, 292 were enrolled in this retrospective study. These patients fulfilled the following criteria: (1) positive for anti-HCV (by a third-generation enzyme immunoassay, Chiron Corp., Emeryville, Calif., USA) and HCV RNA by qualitative or quantitative analysis before combination therapy; (2) treated with IFN $\alpha-2 b$ or PEG-IFN $\alpha$-2b plus RIB combination therapy for 24-48 weeks; (3) did not achieve SVR, defined as negative HCV RNA 24 weeks after cessation of antiviral therapy, based on the COBAS TaqMan HCV test (Roche Diagnostics, Tokyo, Japan); (4) free of HCC, both before and during IFN therapy; (5) infected with a single genotype of HCV-1b; (6) negative for hepatitis B surface antigen (by radioimmunoassay, Dainabot, Tokyo, Japan); (7) free of coinfection with the human immunodeficiency virus; (8) lifetime cumulative alcohol intake $<500 \mathrm{~kg}$ (mild to moderate alcohol intake); (9) free of other types of hepatitis and without hemochromatosis, Wilson disease, primary biliary cirrhosis, alcoholic liver disease and autoimmune liver disease, and (10) had signed a consent form for the study protocol, which had been approved by the human ethics review committee.
Table 1. Profile and laboratory data at the start of IFN+RIB combination therapy of 292 patients infected with HCV-1b who did not achieve SVR

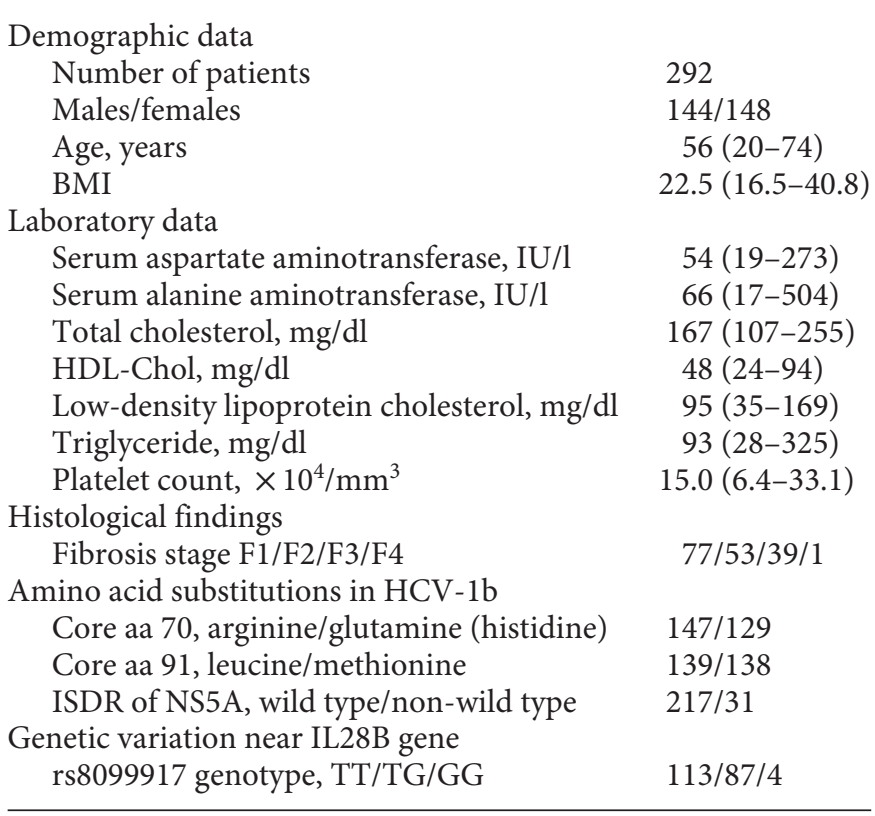

Data represent numbers of patients or medians (range), as appropriate.

Of the total 292 patients, $226(77 \%)$ received PEG-IFN $\alpha-2 b$ at a median dose of $1.4 \mu \mathrm{g} / \mathrm{kg}$ (range $1.3-1.9 \mu \mathrm{g} / \mathrm{kg}$ ) subcutaneously each week for a median duration of 47 weeks (range 28-48 weeks). The remaining 66 patients $(23 \%)$ received 6 million units of IFN $\alpha-2 b$ intramuscularly for a median duration of 27 weeks (range 24-48 weeks), daily for the initial 2 weeks and then 3 times per week until the last week. The dose of RIB was adjusted according to body weight $(600 \mathrm{mg}$ for weight $\leq 60 \mathrm{~kg}, 800 \mathrm{mg}$ for weight $60-80 \mathrm{~kg}$ and $1,000 \mathrm{mg}$ for weight $\geq 80 \mathrm{~kg}$ ).

Table 1 summarizes the profile and laboratory data of the participating patients at the start of combination therapy. The group included 144 males and 148 females aged 20-74 years (median 56 years). The median follow-up period, from the end of antiviral therapy until the last visit, was 1.3 years (range $0.0-8.2$ years).

\section{Laboratory Investigations}

Blood samples were frozen at $-80^{\circ}$ within $4 \mathrm{~h}$ of collection until used for testing. HCV genotype was determined by PCR using a mixed primer set derived from nucleotide sequences of the NS5 region [16]. Quantitative measurement of HCV RNA was analyzed by the COBAS TaqMan HCV test (Roche Diagnostics). The lower limit of the COBAS TaqMan HCV test is $1.2 \mathrm{log} \mathrm{IU} / \mathrm{ml}$, and samples with undetectable levels were defined as negative.

Detection of Amino Acid Substitutions in the Core Region and NS5A Region of $\mathrm{HCV}-1 \mathrm{~b}$

Amino acid substitutions in the core region and NS5A-ISDR of HCV-1b were analyzed by direct sequencing. HCV RNA was 
extracted from serum samples at the start of treatment and reverse transcribed with random primer and Moloney murine leukemia virus reverse transcriptase (Takara Syuzo). Nucleic acids were amplified by PCR. For nucleotide sequences of the core region, the first-round PCR was performed with primers CE1 (sense, 5'-GTC TGC GGA ACC GGT GAG TA-3', nucleotides 134-153) and CE2 (antisense, 5'-GAC GTG GCG TCG TAT TGT CG-3', nucleotides 1096-1115) and the second-round PCR with primers CC9 (sense, 5'-ACT GCT AGC CGA GTA GTG TT-3', nucleotides 234-253) and CE6 (antisense, 5'-GGA GCA GTC GTT CGT GAC AT-3', nucleotides 934-953). For nucleotide sequences of NS5A-ISDR, the first-round PCR was performed with primers ISDR1 (sense, 5'-ATG CCC ATG CCA GGT TCC AG-3', nucleotides 6662-6681) and ISDR2 (antisense, 5'-AGC TCC GCC AAG GCA GAA GA-3', nucleotides 7350-7369) and the secondround PCR with primers ISDR3 (sense, 5'-ACC GGA TGT GGC AGT GCT CA-3', nucleotides 6824-6843) and ISDR4 (antisense, 5'-GTA ATC CGG GCG TGC CCA TA-3', nucleotides 71897208). Nested PCR was used for both the core region and NS5AISDR. All samples were initially denatured at $95^{\circ}$ for $2 \mathrm{~min}$. The 35 cycles of amplification were set as follows: denaturation for $30 \mathrm{~s}$ at $95^{\circ}$, annealing of primers for $30 \mathrm{~s}$ at $55^{\circ}$ and extension for $1 \mathrm{~min}$ at $72^{\circ}$ with an additional $7 \mathrm{~min}$ for extension. Then, $1 \mu \mathrm{l}$ of the first PCR product was transferred to the second PCR reaction. Other conditions for the second PCR were the same as the first PCR, except that the second PCR primers were used instead of the first PCR primers. The amplified PCR products were purified by the QIA quick PCR purification kit (Qiagen) after agarose gel electrophoresis and then used for direct sequencing. Dideoxynucleotide termination sequencing was performed with the Big Dye Deoxy Terminator Cycle Sequencing kit (Perkin-Elmer, Tokyo, Japan).

Using HCV-J (accession No. D90208) as a reference [17], the sequence of aa 1-191 in the core protein of HCV-1b was determined and then compared with the consensus sequence constructed on 279 clinical samples to detect substitutions at aa 70 of arginine (Arg70) or glutamine/histidine (Gln70/His70) and at aa 91 of leucine (Leu91) or methionine (Met91) [18]. The sequence of aa 2209-2248 in the NS5A of HCV-1b (ISDR) reported by Enomoto et al. [19] was determined, and the numbers of amino acid substitutions in ISDR were defined as wild type (0) or non-wild type $(\geq 1)$.

\section{Genetic Variation near the IL28B Gene}

Samples for a genome-wide association survey were genotyped using the Illumina HumanHap610-Quad Genotyping BeadChip. Genotyping data were subjected to quality control before data analysis. Genotyping for replication and fine mapping was performed using the Invader assay, TaqMan assay or direct sequencing as described previously $[20,21]$. In this study, genetic variations near the IL28B gene (rs8099917), reported as the pretreatment predictors of treatment efficacy and clinical outcome [22-26], were investigated.

\section{Histopathological Examination of the Liver}

Liver biopsy specimens were obtained percutaneously or at peritoneoscopy using a modified Vim-Silverman needle with an internal diameter of $2 \mathrm{~mm}$ (Tohoku University style, Kakinuma Factory, Tokyo, Japan), fixed in $10 \%$ formalin and stained with hematoxylin and eosin, Masson's trichrome, silver impregnation and periodic acid-Schiff after diastase digestion. All specimens for examination contained 6 or more portal areas. Histopathological diagnosis was made by an experienced liver pathologist (H.K.) who was blinded to the clinical data. Chronic hepatitis was diagnosed based on histopathological assessment according to the scoring system of Desmet et al. [27].

\section{Follow-Up and Diagnosis of HCC}

Hematological, biochemical and virological tests were performed at least once every month. Imaging studies were conducted every 3 or 4 months in the majority of patients (except those patients who were lost to follow-up); these included computed tomography, magnetic resonance imaging and ultrasonography. If HCC was suspected, additional procedures, such as abdominal angiography and ultrasonography-guided tumor biopsy, if necessary, were used to confirm the diagnosis.

\section{Statistical Analysis}

The cumulative rate of HCC was calculated using the KaplanMeier technique, and differences in the rates were examined by the log-rank test. Differences in the HCC rate among groups were calculated using the period between the end of combination therapy and appearance of HCC. Stepwise Cox regression analysis was used to determine independent predictive factors associated with HCC. Hazard ratios (HRs) and 95\% confidence intervals were also calculated. Potential predictive factors associated with HCC included the following variables: sex, age, type of IFN received, body mass index, platelet count, aspartate aminotransferase, alanine aminotransferase, total cholesterol, high-density lipoprotein cholesterol (HDL-Chol), low-density lipoprotein cholesterol, triglyceride, stage of fibrosis, genetic variation near the IL28B gene and amino acid substitution in the core region and NS5A-ISDR of HCV. Variables that achieved statistical significance $(p<0.05)$ or marginal significance $(p<0.10)$ on univariate analysis were entered into a multivariate Cox proportional hazard model to identify significant independent factors. Statistical comparisons were performed using the SPSS software (SPSS Inc., Chicago, Ill., USA). All p values of less than 0.05 by the two-tailed test were considered significant.

\section{Results}

\section{Rate of Hepatocarcinogenesis}

During the follow-up, 16 patients (5.4\%) developed HCC. The median interval between the end of combination therapy and detection of HCC was 2.0 years (range $0.0-7.6$ years). The cumulative rates of HCC were 5.0, 13.2 and $16.9 \%$ at the end of 3,5 and 7 years, respectively.

\section{Predictive Factors Associated with \\ Hepatocarcinogenesis}

Data of the entire population sample were analyzed to determine those factors that could predict HCC. Univariate analysis identified 4 parameters that tended to or were significantly correlated with carcinogenesis. 

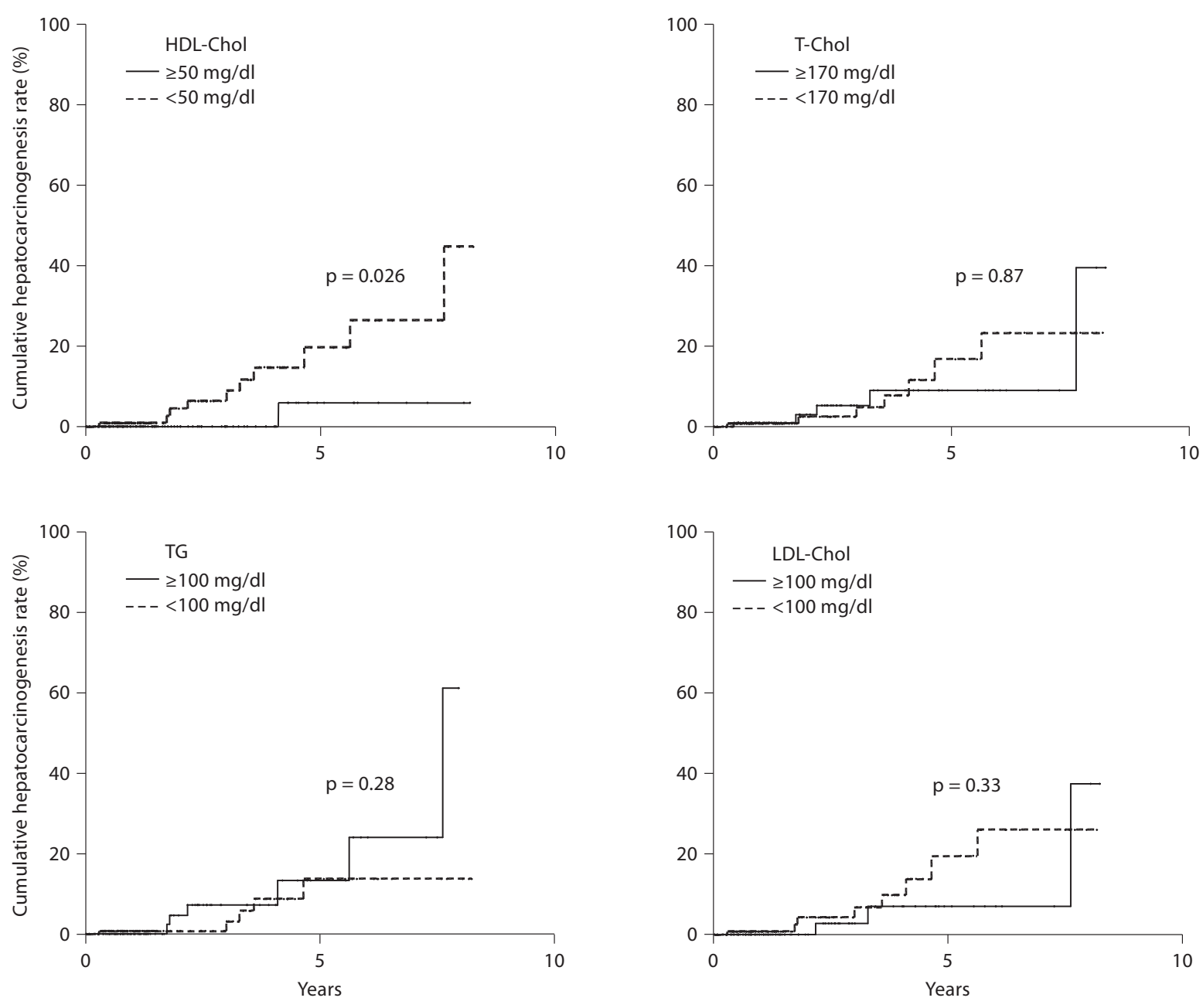

Fig. 1. Cumulative rate of HCC according to serum levels of HDL-Chol, low-density lipoprotein cholesterol (LDL-Chol), total cholesterol (T-Chol) and triglyceride (TG). The rate of HCC was significantly higher for low serum levels of HDL-Chol than high serum levels of HDL-Chol ( $\mathrm{p}=0.026$, log-rank test).

Table 2. Factors associated with hepatocarcinogenesis in patients infected with HCV-1b who did not achieve SVR with IFN+RIB combination therapy, identified by multivariate analysis

\begin{tabular}{|c|c|c|c|}
\hline Factor & Category & HR & $\mathrm{p}$ \\
\hline Core aa 70 & $\begin{array}{l}\text { 1: Arg70 } \\
\text { 2: Gln70/His70 }\end{array}$ & $\begin{array}{l}1 \\
4.64(1.30-16.5)\end{array}$ & 0.018 \\
\hline HDL-Chol & $\begin{array}{l}1: \geq 50 \mathrm{mg} / \mathrm{dl} \\
2:<50 \mathrm{mg} / \mathrm{dl}\end{array}$ & $\begin{array}{l}1 \\
9.35(1.09-83.3)\end{array}$ & 0.041 \\
\hline
\end{tabular}

Cox proportional hazard model. Values in parentheses represent $95 \%$ confidence intervals.
These included age ( $\geq 55$ years; $p=0.093)$, body mass index $(\geq 25 ; \mathrm{p}=0.013)$, HDL-Chol $(<50 \mathrm{mg} / \mathrm{dl} ; \mathrm{p}=$ $0.026)$ and substitution of aa 70 in the HCV core region (Gln70/His70; $\mathrm{p}=0.086$ ). On the other hand, gender, stage of fibrosis and genetic variation near the IL28B gene showed no such correlation. These 4 factors were entered into multivariate analysis, which identified 2 parameters as significant and independent determinants of HCC, namely substitution of aa 70 in the HCV core region (Gln70/His70; HR 4.64, $\mathrm{p}=0.018)$ and serum level of HDL-Chol (<50 mg/dl; HR 9.35, p = 0.041; table 2). 


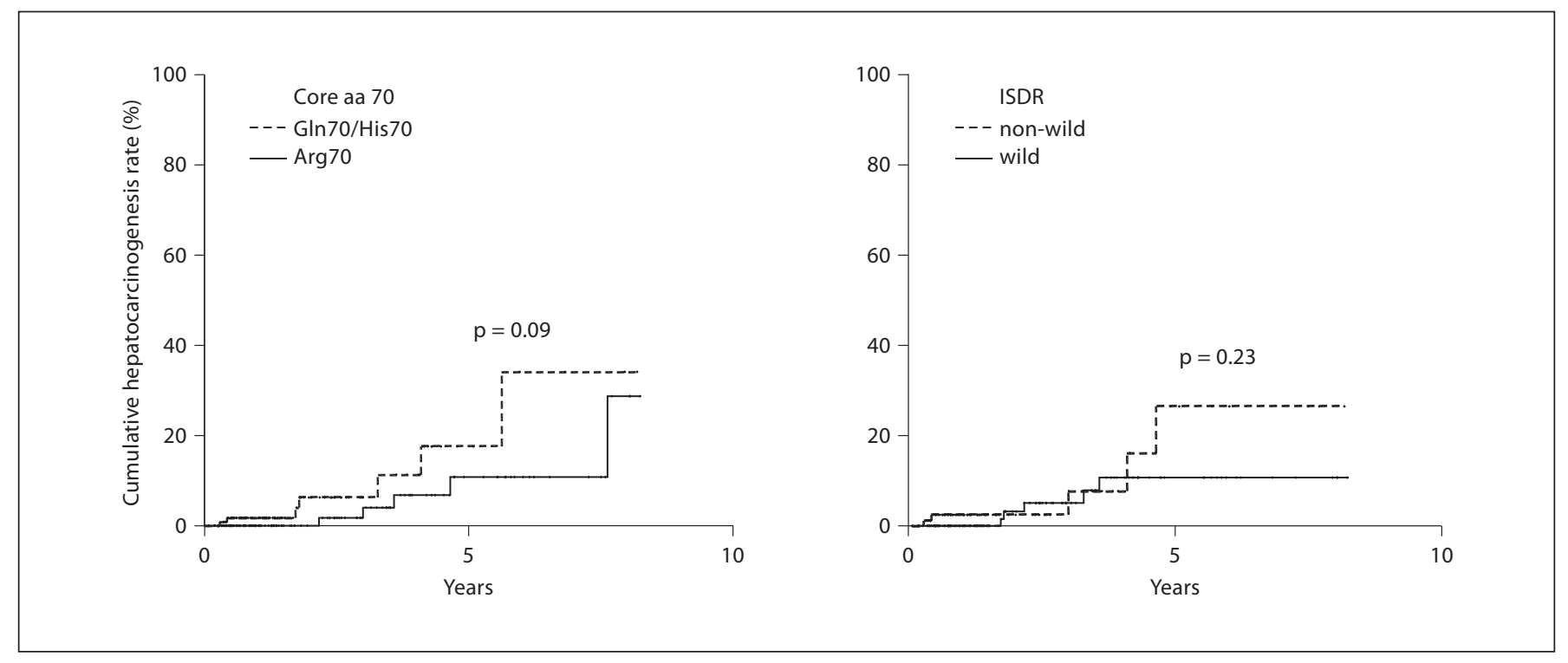

Fig. 2. Cumulative rate of HCC according to amino acid substitutions in the core region of HCV-1b and ISDR of NS5A. The rate of HCC for the Gln70/His70 substitution tended to be higher than that for $\operatorname{Arg} 70$ ( $p=0.086$, log-rank test). There was no significant relationship between ISDR substitution and HCC ( $\mathrm{p}=0.232, \log$-rank test).

Rate of HCC according to Substitution of aa 70 in the HCV Core Region and Serum Level of HDL-Chol

The patients were divided into two groups according to the serum level of HDL-Chol using a cutoff value of 50 $\mathrm{mg} / \mathrm{dl}$ [low HDL-Chol group ( $<50 \mathrm{mg} / \mathrm{dl}), \mathrm{n}=127$, high HDL-Chol group ( $\geq 50 \mathrm{mg} / \mathrm{dl}), \mathrm{n}=115]$. During the follow-up period, 10 patients (8.0\%) in the low HDL-Chol group and $1(1.0 \%)$ in the high HDL-Chol group developed HCC. The median interval between the completion of IFN+RIB therapy and detection of HCC was 3.1 years (range 0.0-7.6 years) and 4.1 years for the low and high HDL-Chol groups, respectively. The respective cumulative rates of HCC in the low and high HDL-Chol groups were 9.0 and $0 \%$ at the end of 3 years, 19.7 and $5.9 \%$ at the end of 5 years, and 26.4 and $5.9 \%$ at the end of 7 years. The rates were significantly different between the two groups ( $\mathrm{p}=0.026$, log-rank test; fig. 1 ).

During the follow-up period, 7 patients (5.7\%) who developed HCC had a Gln70/His70 substitution and 5 (3.5\%) had an Arg70 substitution. The median interval between the completion of IFN+RIB therapy and detection of HCC in patients with Gln70/His70 and Arg70 was 1.8 years (range $0.0-5.6$ years) and 3.6 years (range $0.0-7.6$ years), respectively. The respective cumulative rates of HCC in these patients were 6.3 and $4.0 \%$ at the end of 3 years, 17.6 and $10.8 \%$ at the end of 5 years, and 34.1 and
$10.8 \%$ at the end of 7 years. The rates tended to be different between the two groups $(\mathrm{p}=0.086$, log-rank test; fig. 2)

\section{Discussion}

Previous studies on Japanese patients infected with $\mathrm{HCV}-1 \mathrm{~b}$ reported that IFN+RIB therapy increases the proportion of patients who achieve SVR $[3,28]$ and that the incidence of HCC among patients who achieve SVR is lower than that among patients who do not [7]. In the present study, we examined the incidence and risk factors of HCC in HCV-1b patients who did not achieve SVR after IFN+RIB therapy. Multivariate analysis identified amino acid substitution in the core region of HCV (Gln70/ His70) and serum levels of HDL-Chol ( $<50 \mathrm{mg} / \mathrm{dl})$ as determinants of HCC in such patients. We also examined the risk factors for HCC in HCV-1b patients treated with IFN+RIB therapy. Multivariate analysis identified age ( $>55$ years), body mass index ( $>25$ ), ISDR substitutions (wild type), amino acid substitution in the core region of HCV (Gln70/His70) and serum levels of HDL-Chol $(<50$ $\mathrm{mg} / \mathrm{dl}$ ) as determinants of HCC in such patients (data not shown). This result suggested that the effect of IFN+RIB therapy was independent of amino acid substitution in 


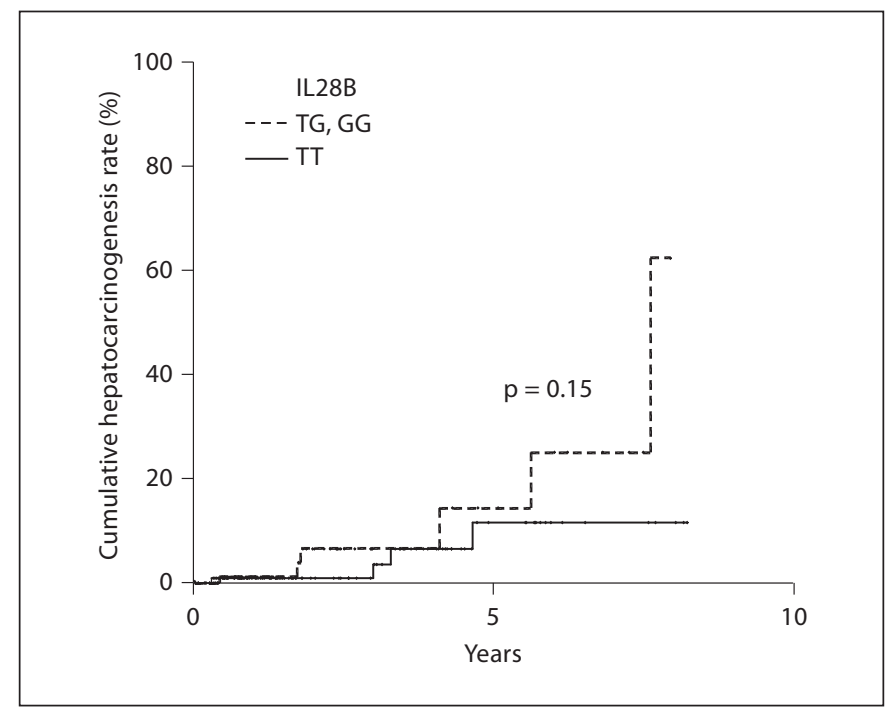

Fig. 3. Cumulative rate of HCC according to genetic variations near the IL28B gene. There was no significant relationship between genetic variations near the IL28B gene and HCC ( $\mathrm{p}=0.153$, log-rank test).

the core region and serum levels of HDL-Chol. In this regard, previous reports identified severe fibrosis, male sex, old age, steatosis, HCV genotype [6, 8-12], ISDR substitutions [13], substitution of aa 70 in the HCV core region [14] and IL28B polymorphisms [15] as risk factors for HCC. In the present study, some of the above factors were not identified as significant predictors. The differences between the findings of the present study and the above reports are not clear at present, but they could reflect differences in the population samples, since we focused on Japanese patients with HCV-1b infection who were treated with IFN+RIB therapy and failed to respond to it. Further studies of larger population samples of other ethnicities are necessary.

In this present study, substitution of aa 70 in the HCV core region was associated with the development of HCC after IFN+RIB therapy. Experiments in transgenic mice have provided evidence for the oncogenic role of the HCV core region [29]. Furthermore, patients infected by HCV$1 \mathrm{~b}$ with amino acid substitutions in the core region are at high risk of HCC [14, 30-32], even after eradication of HCV RNA [33]. In the presence of amino acid substitutions in the core region, IFN-induced phosphorylation of STAT1 and STAT2 is lower, and the expression level of SOCS3, an IFN signal attenuator, was higher than in the wild type. Furthermore, the expression levels of IL-6, which upregulates SOCS3, and those of endoplasmic re- ticulum stress proteins were significantly higher in cells transfected with core mutant compared with the wild type [34]. These mechanisms may explain the resistance to IFN of HCV-1b with amino acid substitutions in the core region. Other studies also described the important role of a PA28 $\gamma$-dependent pathway in the development of HCV-associated HCC. Moriishi et al. [35, 36] reported that knockout of the PA28 $\gamma$ gene induces accumulation of $\mathrm{HCV}$ core protein in the nuclei of hepatocytes of $\mathrm{HCV}$ core gene transgenic mice and disrupts the development of both hepatic steatosis and HCC. Furthermore, HCV core protein is also reported to enhance the binding of liver $\mathrm{X}$ receptor $\alpha /$ retinoid $\mathrm{X}$ receptor $\alpha$ to liver X receptor response element in the presence of PA28 $\gamma$ [36]. Thus, it seems that PA28 $\gamma$ plays a crucial role in the development of HCV-associated steatosis and HCC. Further studies should be performed to investigate the oncogenic potential of amino acid substitution in the core region of $\mathrm{HCV}$ detected at the start of antiviral therapy with regard to HCC after combination therapy.

The relationship between metabolic factors and the risk of HCC is still not clear. Previous studies reported that hepatic steatosis is a significant factor in the development of HCC in HCV-related liver disease independent of age, sex, body mass index, stage of fibrosis and response to antiviral therapy $[9,11]$. Other reports indicated that obesity and diabetes mellitus are risk factors for HCC [37-39]. It is also reported that HCV core protein is involved in mitochondrial electron transfer system dysfunction and activation of peroxisome proliferatoractivated receptor- $\alpha$ (PPAR $\alpha)$. In the presence of mitochondrial dysfunction, PPAR $\alpha$ exacerbates steatosis, and persistent activation of PPAR $\alpha$ contributes to hepatocarcinogenesis by inducing overproduction of reactive oxygen species and cell growth signal activation [12]. In this present study, multivariate analysis identified amino acid substitution in the core region of $\mathrm{HCV}$ and low levels of HDL-Chol as determinants of HCC. These results are not inconsistent with previous studies. Interestingly, in our patients, the impact of amino acid substitution in the core region of HCV and low levels of HDL-Chol was more significant than that of gender, age and stage of fibrosis. One of the reasons for this finding could be the nature of the population study, i.e. Japanese patients treated with IFN+RIB.

Genetic variations near the IL28B gene are pretreatment predictors of a poor virological response to PEGIFN/RIB combination therapy and triple therapy with telaprevir/PEG-IFN/RIB [22-25, 40]. It has recently been reported that the IL-28B rs12979860 C/T polymorphism 
$\mathrm{T}$ allele is more prevalent in patients with HCV-related cirrhosis than other etiologies and mild chronic hepatitis $\mathrm{C}$, and also in patients with HCC than in those without HCC [15]. However, the link between IL-28B and HCC remains unclear. In the present study, genetic variations near the IL28B gene did not significantly affect HCC (fig. 3). This discrepant result might be related to differences in the etiology, including hepatitis B virus, alcohol intake and HCV-related liver disease. The population of this study consisted of Japanese patients infected with HCV-1b who were treated with IFN+RIB. Further studies should be conducted to investigate the relationship between genetic variations near the IL28B gene and HCC.

Our study has certain limitations. Firstly, the study did not provide a comprehensive analysis of the viral factors and their role in the development of HCC. Experimental evidence suggests that the pathogenic role of HCV-1b strains in HCC is based on the secondary structure of the amino-terminal portion of the HCV NS3 protein [41]. In the present study, we did not investigate the roles of viral factors except for the HCV core region and NS5A region. Another limitation of the study is the lack of analysis of the clinical impact of lifestyle-related diseases (such as diabetes, insulin resistance, nonalcoholic steatohepatitis) on HCC, except for body mass index and cholesterol levels $[38,39,42,43]$. Further studies are needed to investigate the clinical impact of viral factors and lifestyle-related diseases on HCC.

We previously indicated that substitution of aa 70 in the HCV-1b core region might predict elevation of serum $\alpha$-fetoprotein levels in non-HCC patients and that eradication of HCV-1b with Gln70/His70 seemed to induce normalization of $\alpha$-fetoprotein [44]. To investigate $\alpha$-fetoprotein during and after PEG-IFN+RIB therapy, according to the substitution pattern of aa 70 , is important for evaluating the risk of hepatocarcinogenesis, especially in nonresponders. Further understanding of the complex interaction between $\alpha$-fetoprotein levels and substitution of aa 70 in the $\mathrm{HCV}-1 \mathrm{~b}$ core region should facilitate the development of more effective therapeutic regimens.

In conclusion, the present study identified amino acid substitution in the core region of HCV-1b and low levels of HDL-Chol as significant and independent predictors of HCC in nonresponders to the combination of IFN+RIB. The study emphasizes the importance of viral and lipid metabolic factors in hepatocarcinogenesis after combination therapy.

\section{Acknowledgment}

This study was supported in part by a Grant-in-Aid from the Ministry of Health, Labor and Welfare, Japan.

\section{References}

1 Niederau C, Lange S, Heintges T, Erhardt A, Buschkamp M, Hürter D, Nawrocki M, Kruska L, Hensel F, Petry W, Häussinger D: Progress of chronic hepatitis C: results of a large, prospective cohort study. Hepatology 1998;28:1687-1695.

2 Kenny-Walsh E: Clinical outcomes after hepatitis $\mathrm{C}$ infection from contaminated anti-D immune globulin. Irish Hepatology Research Group. N Engl J Med 1999;340:12281233.

3 Tsubota A, Arase Y, Someya T, Suzuki Y, Suzuki F, Saitoh S, Ikeda K, Akuta N, Hosaka T, Kobayashi M, Kumada H: Early viral kinetics and treatment outcome in combination of high-dose interferon induction vs. pegylated interferon plus ribavirin for naive patients infected with hepatitis $C$ virus of genotype $1 \mathrm{~b}$ and high viral load. J Med Virol 2005;75: 27-34.

4 NishiguchiS, Kuroki T, NakataniS, Morimoto H, Takeda T, Nakajima S, Shiomi S, Seki S, Kobayashi K, Otani S: Randomized trial of effects of interferon-alpha on incidence of hepatocellular carcinoma in chronic active hepatitis C with cirrhosis. Lancet 1995;346: 1051-1055.

5 Yoshida H, Shiratori Y, Moriyama M, Arakawa Y, Ide T, Sata M, Inoue O, Yano M, Tanaka M, Fujiyama S, Nishiguchi S, Kuroki T, Imazeki F, Yokosuka O, Kinoyama S, Yamada G, Omata M: Interferon therapy reduces the risk for hepatocellular carcinoma: national surveillance program of cirrhotic and noncirrhotic patients with chronic hepatitis C in Japan. IHIT Study Group. Inhibition of hepatocarcinogenesis by interferon therapy. Ann Intern Med 1999;131:174-181.

6 Ikeda K, Saitoh S, Arase Y, Chayama K, Suzuki Y, Kobayashi M, Tsubota A, Nakamura I, Murashima N, Kumada H, Kawanishi M: Effect of interferon therapy on hepatocellular carcinogenesis in patients with chronic hepatitis type C: a long-term observation study of 1,643 patients using statistical bias correction with proportional hazard analysis. Hepatology 1999;29:1124-1130.

-7 Kurokawa M, Hiramatsu N, Oze T, Mochizuki K, Yakushijin T, Kurashige N, Inoue Y, Igura T, Imanaka K, Yamada A, Oshita M,
Hagiwara H, Mita E, Ito T, Inui Y, Hijioka T, Yoshihara H, Inoue A, Imai Y, Kato M, Kiso S, Kanto T, Takehara T, Kasahara A, Hayashi $\mathrm{N}$ : Effect of interferon $\alpha-2 \mathrm{~b}$ plus ribavirin therapy on incidence of hepatocellular carcinoma in patients with chronic hepatitis. Hepatol Res 2009;39:432-438.

8 Freeman AJ, Dore GJ, Law MG, Thorpe M, Von Overbeck J, Lloyd AR, Marinos G, Kaldor JM: Estimating progression to cirrhosis in chronic hepatitis $C$ virus infection. Hepatology 2001;34:809-816.

$\checkmark 9$ Ohata K, Hamasaki K, Toriyama K, Matsumoto K, Saeki A, Yanagi K, Abiru S, Nakagawa Y, Shigeno M, Miyazoe S, Ichikawa T, Ishikawa H, Nakao K, Eguchi K: Hepatic steatosis is a risk factor for hepatocellular carcinoma in patients with chronic hepatitis $\mathrm{C}$ virus infection. Cancer 2003;97:3036-3043.

10 Bruno S, Crosignani A, Maisonneuve P, Rossi S, Silini E, Mondelli MU: Hepatitis C virus genotype $\mathrm{lb}$ as a major risk factor associated with hepatocellular carcinoma in patients with cirrhosis: a seventeen-year prospective cohort study. Hepatology 2007;46:1350-1356. 
11 Kurosaki M, Hosokawa T, Matsunaga K, Hirayama I, Tanaka T, Sato M, Yasui Y, Tamaki N, Ueda K, Tsuchiya K, Kuzuya T, Nakanishi H, Itakura J, Takahashi Y, Asahina Y, Enomoto N, Izumi N: Hepatic steatosis in chronic hepatitis $\mathrm{C}$ is a significant risk factor for developing hepatocellular carcinoma independent of age, sex, obesity, fibrosis stage and response to interferon therapy. Hepatol Res 2010;40:870-877.

$\checkmark 12$ Koike K, Tsutsumi T, Yotsuyanagi H, Moriya $\mathrm{K}$ : Lipid metabolism and liver disease in hepatitis C viral infection. Oncology 2010;78: 24-30.

-13 Giménez-Barcons M, Franco S, Suárez Y, Forns X, Ampurdanès S, Puig-Basagoiti F, Sánchez-Fueyo A, Barrera JM, Llovet JM, Bruix J, Sánchez-Tapias JM, Rodés J, Saiz JC: High amino acid variability within the NS5A of hepatitis $\mathrm{C}$ virus (HCV) is associated with hepatocellular carcinoma in patients with HCV-1b-related cirrhosis. Hepatology 2001; 34:158-167.

- 14 Akuta N, Suzuki F, Kawamura Y, Yatsuji H, Sezaki H, Suzuki Y, Hosaka T, Kobayashi M, Kobayashi M, Arase Y, Ikeda K, Kumada H: Amino acid substitutions in the hepatitis $\mathrm{C}$ virus core region are the important predictor of hepatocarcinogenesis. Hepatology 2007; 46:1357-1364.

-15 Fabris C, Falleti E, Cussigh A, Bitetto D, Fontanini E, Bignulin S, Cmet S, Fornasiere E, Fumolo E, Fangazio S, Cerutti A, Minisini R, Pirisi M, Toniutto P: IL-28B rs12979860 C/T allele distribution in patients with liver cirrhosis: Role in the course of chronic viral hepatitis and the development of HCC. J Hepatol 2011;54:716-722.

$\checkmark 16$ Chayama K, Tsubota A, Arase Y, Saitoh S, Koida I, Ikeda K, Matsumoto T, Kobayashi M, Iwasaki S, Koyama S, Morinaga T, Kumada $\mathrm{H}$ : Genotypic subtyping of hepatitis C virus. J Gastroenterol Hepatol 1993;8:150156.

17 Kato N, Hijikata M, Ootsuyama Y, Nakagawa M, Ohkoshi S, Sugimura T, Shimotohno $\mathrm{K}$ : Molecular cloning of the human hepatitis $\mathrm{C}$ virus genome from Japanese patients with non-A, non-B hepatitis. Proc Natl Acad Sci USA 1990;87:9524-9528.

18 Akuta N, Suzuki F, Sezaki H, Suzuki Y, Hosaka T, Someya T, Kobayashi M, Saitoh S, Watahiki S, Sato J, Matsuda M, Kobayashi M, Arase Y, Ikeda K, Kumada H: Association of amino acid substitution pattern in core protein of hepatitis $C$ virus genotypelb high viral load and non-virological response to interferon-ribavirin combination therapy. Intervirology 2005;48:372-380.

19 Enomoto N, Sakuma I, Asahina Y, Kurosaki M, Murakami T, Yamamoto C, Ogura Y, Izumi N, Marumo F, Sato C: Mutations in the nonstructural protein $5 \mathrm{~A}$ gene and response to interferon in patients with chronic hepatitis $C$ virus $1 b$ infection. N Engl J Med 1996; 334:77-81.
20 Ohnishi Y, Tanaka T, Ozaki K, Yamada R, Suzuki H, Nakamura Y: A high-throughput SNP typing system for genome-wide association studies. J Hum Genet 2001;46:471-477.

21 Suzuki A, Yamada R, Chang X, Tokuhiro S, Sawada T, Suzuki M, Nagasaki M, Nakayama-Hamada M, Kawaida R, Ono M, Ohtsuki M, Furukawa H, Yoshino S, Yukioka M, Tohma S, Matsubara T, Wakitani S, Teshima R, Nishioka Y, Sekine A, Iida A, Takahashi A, Tsunoda T, Nakamura Y, Yamamoto K: Functional haplotypes of PADI4, encoding citrullinating enzyme peptidylarginie deminase 4, are associated with rheumatoid arthritis. Nat Genet 2003;34:395-402.

22 Ge D, Fellay J, Thompson AJ, Simon JS, Shianna KV, Urban TJ, Heinzen EL, Qiu P, Bertelsen AH, Muir AJ, Sulkowski M, McHutchison JG, Goldstein DB: Genetic variation in IL28B predicts hepatitis C treatment-induced viral clearance. Nature 2009;461:399401.

23 Tanaka Y, Nishida N, Sugiyama M, Kurosaki M, Matsuura K, Sakamoto N, Nakagawa M, Korenaga M, Hino K, Hige S, Ito Y, Mita E, Tanaka E, Mochida S, Murawaki Y, Honda M, Sakai A, Hiasa Y, Nishiguchi S, Koike A, Sakaida I, Imamura M, Ito K, Yano K, Masaki N, Sugauchi F, Izumi N, Tokunaga K, Mizokami M: Genome-wide association of IL28B with response to pegylated interferonalpha and ribavirin therapy for chronic hepatitis C. Nat Genet 2009;41:1105-1109.

-24 Suppiah V, Moldovan M, Ahlenstiel G, Berg T, Weltman M, Abate ML, Bassendine M, Spengler U, Dore GJ, Powell E, Riordan S, Sheridan D, Smedile A, Fragomeli V, Müller T, Bahlo M, Stewart GJ, Booth DR, George J: IL28B is associated with response to chronic hepatitis $\mathrm{C}$ interferon-alpha and ribavirin therapy. Nat Genet 2009;41:1100-1104.

25 Rauch A, Kutalik Z, Descombes P, Cai T, Di Iulio J, Mueller T, Bochud M, Battegay M, Bernasconi E, Borovicka J, Colombo S, Cerny A, Dufour JF, Furrer H, Günthard HF, Heim M, Hirschel B, Malinverni R, Moradpour D, Müllhaupt B, Witteck A, Beckmann JS, Berg T, Bergmann S, Negro F, Telenti A, Bochud PY: Genetic variation in IL28B is associated with chronic hepatitis $\mathrm{C}$ and treatment failure: a genome-wide association study. Gastroenterology 2010;138:1338-1345.

26 Thomas DL, Thio CL, Martin MP, Qi Y, Ge D, O'Huigin C, Kidd J, Kidd K, Khakoo SI, Alexander G, Goedert JJ, Kirk GD, Donfield SM, Rosen HR, Tobler LH, Busch MP, McHutchison JG, Goldstein DB, Carrington M: Genetic variation in IL28B and spontaneous clearance of hepatitis $\mathrm{C}$ virus. Nature 2009;8;461:798-801.

27 Desmet VJ, Gerber M, Hoofnagle JH, Manna M, Scheuer PJ: Classification of chronic hepatitis: Diagnosis, grading and staging. Hepatology 1994;19:1513-1520.
28 Akuta N, Suzuki F, Kawamura Y, Yatsuji H, Sezaki H, Suzuki Y, Hosaka T, Kobayashi M, Kobayashi M, Arase Y, Ikeda K, Kumada H: Predictive factors of early and sustained responses to peginterferon plus ribavirin combination therapy in Japanese patients infected with hepatitis $C$ virus genotype $1 \mathrm{~b}$ : amino acid substitutions in the core region and lowdensity lipoprotein cholesterol levels. J Hepatol 2007;46:403-410.

29 Moriya K, Fujie H, Shintani Y, Yotsuyanagi $\mathrm{H}$, Tsutsumi T, Ishibashi K, Matsuura Y, Kimura S, Miyamura T, Koike K: The core protein of hepatitis $\mathrm{C}$ virus induces hepatocellular carcinoma in transgenic mice. Nat Med 1998;4:1065-1067.

30 Fishman SL, Factor SH, Balestrieri C, Fan X, Dibisceglie AM, Desai SM, Benson G, Branch AD: Mutations in the hepatitis C virus core gene are associated with advanced liver disease and hepatocellular carcinoma. Clin Cancer Res 2009;15:3205-3213.

-31 Hu Z, Muroyama R, Kowatari N, Chang J, Omata M, Kato N: Characteristic mutations in hepatitis $\mathrm{C}$ virus core gene related to the occurrence of hepatocellular carcinoma. Cancer Sci 2009;100:2465-2468.

32 Nakamoto S, Imazeki F, Fukai K, Fujiwara K, Arai M, Kanda T, Yonemitsu Y, Yokosuka O: Association between mutations in the core region of hepatitis $\mathrm{C}$ virus genotype 1 and hepatocellular carcinoma development. J Hepatol 2010;52:72-78.

33 Akuta N, Suzuki F, Hirakawa M, Kawamura Y, Sezaki H, Suzuki Y, Hosaka T, Kobayashi M, Kobayashi M, Saitoh S, Arase Y, Ikeda K, Kumada H: Amino acid substitutions in hepatitis $\mathrm{C}$ virus core region predict hepatocarcinogenesis following eradication of $\mathrm{HCV}$ RNA by antiviral therapy. J Med Virol 2011; 83:1016-1022.

34 Funaoka Y, Sakamoto N, Suda G, Itsui Y, Nakagawa M, Kakinuma S, Watanabe T, Mishima K, Ueyama M, Onozuka I, Nitta S, Kitazume A, Kiyohashi K, Murakawa M, Azuma S, Tsuchiya K, Watanabe M: Analysis of interferon signaling by infectious hepatitis $\mathrm{C}$ virus clones with substitutions of core amino acids 70 and 91. J Virol 2011;85:59865994.

-35 Moriishi K, Okabayashi T, Nakai K, Moriya K, Koike K, Murata S, Chiba T, Tanaka K, Suzuki R, Suzuki T, Miyamura T, Matsuura Y: Proteasome activator PA28gamma-dependent nuclear retention and degradation of hepatitis C virus core protein. J Virol 2003; 77:10237-10249.

36 Moriishi K, Mochizuki R, Moriya K, Miyamoto H, Mori Y, Abe T, Murata S, Tanaka K, Miyamura T, Suzuki T, Koike K, Matsuura Y: Critical role of PA28gamma in hepatitis C virus-associated steatogenesis and hepatocarcinogenesis. Proc Natl Acad Sci USA 2007;104:1661-1666. 
37 Polesel J, Zucchetto A, Montella M, Dal Maso L, Crispo A, La Vecchia C, Serraino D, Franceschi S, Talamini R: The impact of obesity and diabetes mellitus on the risk of hepatocellular carcinoma. Ann Oncol 2009;20: 353-357.

-38 Kawamura Y, Arase Y, Ikeda K, Hirakawa M, Hosaka T, Kobayashi M, Saitoh S, Yatsuji H, Sezaki H, Akuta N, Suzuki F, Suzuki Y, Kumada H: Diabetes enhances hepatocarcinogenesis in noncirrhotic, interferon-treated hepatitis C patients. Am J Med 2010;123: 951-956.

39 Sumida Y, Kanemasa K, Hara T, Inada Y, Sakai K, Imai S, Yoshida N, Yasui K, Itoh Y, Okanoue T, Yoshikawa T: Impact of amino acid substitutions in hepatitis $\mathrm{C}$ virus genotype $1 \mathrm{~b}$ core region on liver steatosis and glucose tolerance in non-cirrhotic patients without overt diabetes. J Gastroenterol Hepatol 2011;26:836-842.
40 Akuta N, Suzuki F, Hirakawa M, Kawamura Y, Yatsuji H, Sezaki H, Suzuki Y, Hosaka T, Kobayashi M, Kobayashi M, Saitoh S, Arase Y, Ikeda K, Chayama K, Nakamura Y, Kumada H: Amino acid substitution in $\mathrm{HCV}$ core region and genetic variation near the interleukin $28 \mathrm{~B}$ gene predict viral response to telaprevir with peginterferon and ribavirin. Hepatology 2010;52:421-429.

41 Ogata S, Florese RH, Nagano-Fujii M, Hidajat R, Deng L, Ku Y, Yoon S, Saito T, Kawata $\mathrm{S}$, Hotta H: Identification of hepatitis $\mathrm{C}$ virus ( $\mathrm{HCV}$ ) subtype $1 \mathrm{~b}$ strains that are highly, or only weakly, associated with hepatocellular carcinoma on the basis of the secondary structure of an amino-terminal portion of the HCV NS3 protein. J Clin Microbiol 2003; 41:2835-2841.
42 Mason AL, Lau JY, Hoang N, Qian K, Alexander GJ, Xu L, Guo L, Jacob S, Regenstein FG, Zimmerman R, Everhart JE, Wasserfall C, Maclaren NK, Perrillo RP: Association of diabetes mellitus and chronic hepatitis $\mathrm{C}$ virus infection. Hepatology 1999;29:328-333.

43 El-Serag HB, Tran T, Everhart JE: Diabetes increases the risk of chronic liver disease and hepatocellular carcinoma. Gastroenterology 2004;126:460-468.

44 Akuta N, Suzuki F, Kawamura Y, Yatsuji H, Sezaki H, Suzuki Y, Hosaka T, Kobayashi M, Kobayashi M, Arase Y, Ikeda K, Kumada H: Substitution of amino acid 70 in the hepatitis $\mathrm{C}$ virus core region of genotype $1 \mathrm{~b}$ is an important predictor of elevated alpha-fetoprotein in patients without hepatocellular carcinoma. J Med Virol 2008;80:1354-1362. 